\title{
Pulmonary dysfunction in gold miners with reactive airways
}

\author{
R L COWIE \\ From the Ernest Oppenheimer Hospital, Welkom, South Africa 9460
}

\begin{abstract}
In a cross sectional study of a working population of black South African gold miners a sample of 1197 older miners was examined. Airway reactivity determined by a greater than $10 \%$ response of the forced expiratory volume in one second $\left(\mathrm{FEV}_{1}\right)$ to inhaled salbutamol was detected in $139(12 \%)$ of the men. No relation was found between the extent of exposure to the underground environment and the frequency of airway reactivity. There was evidence of increased chronic airflow limitation in the men with reactive airways. This increase persisted after controlling for age, tobacco smoking, and for the presence and degree of silicosis. On average, the presence of reactive airways was associated with reduced (after bronchodilator) forced vital capacity (FVC) of $118 \mathrm{ml}, 95 \%$ confidence interval (CI) 16 to $220 \mathrm{ml}, \mathrm{FEV}_{1}$ of $168 \mathrm{ml}(95 \% \mathrm{CI} 74-262 \mathrm{ml}), \mathrm{FEV}_{1} / \mathrm{FVC}^{2}$ of $3 \%$ (95\% CI 2.3-3.7\%), and maximal mid-expiratory flow of $300 \mathrm{ml} / \mathrm{s}$ (95\% CI 86-514 ml/s). Although there was no evidence that airway reactivity was induced by this occupational exposure, those with reactive airways appeared to be more susceptible to the adverse effects of the underground environment on the bronchial tree.
\end{abstract}

Airway reactivity may be described as a state of hyperresponsiveness of the bronchi that is shown by their constriction in response to generally innocuous stimuli. Airway reactivity is probably the hallmark of asthma and is also apparent in a proportion of the population who are not considered to be asthmatic. In their study of the epidemiology of chronic airflow limitation (CAL) Dutch workers hypothesised that CAL occurs predominantly in smokers, whose airways are hyperresponsive.' There is increasing acceptance of this view and every reason to believe that individuals who respond to atmospheric pollution in the workplace may also be thus predisposed by their airway reactivity. ${ }^{2}$

In large population surveys measurement of airway reactivity by provocation testing is time consuming, potentially dangerous, and uncomfortable for the subjects. ${ }^{3}$ Attempts have been made to establish whether airway reactivity could be predicted by respiratory questionnaires.

In the present study a group of gold miners was examined to determine the prevalence of airway reactivity and examine its relation to lung function and to respiratory symptoms.

Accepted 6 February 1989

\section{Methods}

The study population was a working population of black men employed underground in the gold mines in the Orange Free State province of South Africa. The sampling frame consisted of men who were found on routine radiological surveillance to have silicosis ${ }^{4}$ and men without silicosis matched for age and for the day of their miniature chest radiographs with each man with silicosis. The purpose of the design of this sampling frame was to select men with considerable exposure to the mining environment and to obtain good contrast with silicosis, the determinant of interest for the purpose of the main object of the study (which is presented elsewhere ${ }^{5}$ ). The study sample was selected by inviting participation from men with silicosis and men without silicosis in a ratio of $5: 2$ consecutively, in the same order in which they had been entered into the sampling frame, until the predetermined end of the study period.

Each man who participated in the study answered an occupational questionnaire and a respiratory questionnaire, each conducted by an interviewer. The questionnaires were specifically designed for this population and were conducted in each subject's language. One interviewer, fluent in the Zulu, Xhosa, South Sotho, and Tswana languages, conducted all the respiratory questionnaires whereas several inter- 
viewers, employed as hospital clerks, conducted the occupational questionnaires. After the questionnaires, each subject performed lung function tests with expiratory flow volume curves measured before and 10 minutes after salbutamol $200 \mu \mathrm{g}$ by inhalation from a metered dose inhaler. The lung function tests were conducted according to the American Thoracic Society guidelines ${ }^{6}$ with the exception that the best forced expiratory curve, before and after salbutamol, was accepted in the event that there was a progessive fall in the measurements with successive forced expiratory manoeuvres. The best forced expiratory curve, whether before or after bronchodilator, was recorded for analysis. The lung function tests were measured with a Morgan Transfertest model A incorporating an eight litre dry rolling seal spirometer and a flow volume differentiator linked to a Medical Graphics analogue digital converter and an Apple 2e computer with Medical Graphics operating software.

After the lung function studies, each man had a full size posteroanterior $125 \mathrm{kV}$ chest radiograph that was read, independently, by two readers using the International Labour Office standard guidelines and standard radiographs. ${ }^{\text {? }}$

The data were analysed by Chi squared testing of contingency tables for dichotomous variables, by Student's $t$ test for continuous variables, and by multiple linear regression ${ }^{8}$ when several independent variables required simultaneous analysis or control.

\section{Definition}

For the purpose of this study, airway reactivity was considered to be present when the postsalbutamol forced expiratory volume in one second $\left(\mathrm{FEV}_{1}\right)$ was greater than $110 \%$ of the presalbutamol $\mathrm{FEV}_{1}$.

\section{Results}

Fifty men were excluded from the analysis because they could not perform the lung function tests leaving 1197 men participating in all parts of the study. Airway reactivity was detected in $139(12 \%)$ of the men and a history of wheezing was obtained in 272 $(23 \%)$. The mean age of the men was $46 \cdot 1$ years (SD 6.88) and their mean duration of exposure to the mine environment was $25 \cdot 1$ years (SD 7.69). No significant relation between airway reactivity and duration of exposure was apparent. No radiographic evidence of silicosis was apparent in $\mathbf{3 4 0}$ of the subjects; $\mathbf{4 3 2}$ men had category 1 nodule profusion, 376 category 2 , and 49 category 3 . No radiograph was read as $0 /$ - or as $3 /$ + and the radiographic findings were analysed as a 10 category "continuous" variable. No relation was found between the presence or extent of silicosis and airway reactivity. There were 622 current smokers, 225 ex-smokers, and 350 non-smokers. Airway reactivityㅡㅡ was detected in $10.3 \%$ of the smokers, which did not? differ from the $11 \cdot 1 \%$ of the non-smokers but dido differ from the $16.0 \%$ of the ex-smokers with airway reactivity $(p=0.023)$. Tables 1 and 2 present the features of the men with and without airway reactivity.

The significant reduction in the FVC $(\mathrm{p}=0.031)$, $\mathrm{FEV}_{1}(\mathrm{p}=0.0007), \mathrm{FEV}_{1} / \mathrm{FVC}^{\circ}(\mathrm{p}=0.0010)$, and $\frac{\bar{s}}{\bar{\sigma}}$ maximal mid-expiratory flow $(p=0.0087)$ attributa- $-\bar{Q}$ ble to the presence of airway reactivity persisted whiles controlling for other variables including duration of occupational exposure, age, smoking, and silicosis by. multiple linear regression analyses.

Airway reactivity was detected in significantly moreo $(24 \%)$ of the 34 men with $F E V_{1}$ of 2 lor less $(p<0.05)$. No significant relation, between the frequency of? airway reactivity and the $\mathrm{FEV}_{1}$ was apparent in the

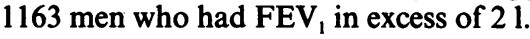

Table 1 Continuous variables by airway reactivity

\begin{tabular}{|c|c|c|c|c|c|c|}
\hline \multirow[b]{2}{*}{ Variable } & \multicolumn{2}{|c|}{$\begin{array}{l}\text { Normal } \\
\text { reactivity } \\
(1058)\end{array}$} & \multicolumn{2}{|c|}{$\begin{array}{l}\text { Hyperreactivity } \\
\text { (139) }\end{array}$} & \multirow[b]{2}{*}{$t$} & \multirow{2}{*}{$p_{(2 \text { tail })}$} \\
\hline & Mean & $S D$ & Mean & $S D$ & & \\
\hline $\begin{array}{l}\text { FVC \% pred } \\
\text { FEV , \% pred } \\
\text { FEV /FVC \% } \\
\text { MMEF \% pred } \\
\text { DICO \% pred } \\
\text { Yrs u/grd } \\
\text { Age (y) } \\
x \text { Ray (1-10) } \\
\text { Pack-years }\end{array}$ & $\begin{array}{r}93 \cdot 9 \\
89 \cdot 7 \\
79.6 \\
81 \cdot 8 \\
100 \cdot 6 \\
25 \cdot 1 \\
46 \cdot 2 \\
4.4 \\
9.4\end{array}$ & $\begin{array}{r}13 \cdot 43 \\
15 \cdot 24 \\
8 \cdot 74 \\
33 \cdot 02 \\
18 \cdot 65 \\
7 \cdot 67 \\
6 \cdot 82 \\
2 \cdot 50 \\
9 \cdot 37\end{array}$ & $\begin{array}{r}91 \cdot 3 \\
84.9 \\
76.9 \\
73 \cdot 9 \\
102 \cdot 2 \\
25 \cdot 0 \\
45 \cdot 6 \\
4.4 \\
9 \cdot 1\end{array}$ & $\begin{array}{r}13 \cdot 84 \\
17 \cdot 60 \\
11 \cdot 89 \\
36 \cdot 34 \\
19 \cdot 25 \\
7 \cdot 85 \\
7 \cdot 32 \\
2 \cdot 62 \\
8 \cdot 78\end{array}$ & $\begin{array}{r}2.16 \\
3.39 \\
3.30 \\
2.63 \\
-0.99 \\
0.22 \\
0.95 \\
-0.01 \\
0.28\end{array}$ & $\begin{array}{l}0.0312 \\
0.000 \Phi \\
0.001 \Theta \\
0.008 \AA \\
0.324 \bar{\Phi} \\
0.8299 \\
0.3448 \\
0.9933 \\
0.7725\end{array}$ \\
\hline
\end{tabular}

FVC, FEV , MMEF (maximal mid-expiratory flow rate), and DICO (single breath lung diffusion for carbon monoxide) are all expressed $\vec{\overline{ }}$ as the percentage of the measure predicted on the basis of age and height." The FEV,/FVC\% is expressed as such. Yrs u/grd is the number of years since starting work underground in a gold mine. $x$ Ray (1-10) reflects the extent of silicosis with one and two equivalent to the ILO $^{7}$ categories $0 / 0$ and $0 / 1$ and 10 as ILO $3 / 3$. Pack-years is a summary of the smoking history expressed as the number of years of smoking about 20 cigarettes a day.

Table 2 Dichotomous variables by airway reactivity

\begin{tabular}{|c|c|c|c|c|}
\hline Variable & $\begin{array}{l}\text { Normal } \\
\text { reactivity } \\
1058\end{array}$ & $\begin{array}{l}\text { Hyper- } \\
\text { reactivity } \\
139\end{array}$ & $\chi^{2}$ & $p$ \\
\hline $\begin{array}{l}\text { Dyspnoea } \\
\text { Cough } \\
\text { Sputum } \\
\text { Wheeze } \\
\text { Variable dyspnoea } \\
\text { Dyspnoea at night } \\
\text { Nocturnal cough } \\
\text { Child chest illness }\end{array}$ & $\begin{array}{r}265 \\
810 \\
651 \\
232 \\
215 \\
59 \\
419 \\
336\end{array}$ & $\begin{array}{l}40 \\
33 \\
96 \\
40 \\
35 \\
10 \\
65 \\
45\end{array}$ & $\begin{array}{l}0.90 \\
0.00 \\
2.97 \\
3 \cdot 28 \\
1 \cdot 79 \\
0.21 \\
2 \cdot 61 \\
0.02\end{array}$ & $\begin{array}{l}0.343 \\
0.937 \\
0.085 \\
0.070 \\
0.181 \\
0.659 \\
0.100 \\
0.883\end{array}$ \\
\hline
\end{tabular}

Dyspnoea was judged to be present if present with walking upstairso or up hills or with any less strenuous activity.

Child chest illness refers to any chest illness during childhood that the subject recalled or had been told of by a parent. 
Of the 272 men with a history of wheezing, only $\mathbf{4 0}$ had reactive airways. Thus a history of wheezing had a positive predictive value of $15 \%$ for airway reactivity. The positive predictive value for airway reactivity of a history of nocturnal dyspnoea was $14 \%$ as was that of variable dyspnoea whereas the value of nocturnal coughing was $13 \%$.

\section{Discussion}

In this study the definition of airway reactivity differs from conventional definitions based on the dose of inhaled methacholine or histamine which produces a drop of $20 \%$ in the $\mathrm{FEV}_{1}$. The definition using a response to a beta-adrenergic agonist has been used by others $^{10-12}$ and is considered by several other authors to be comparable with that determined by provocation. ${ }^{1314}$ The bronchodilator response is probably less sensitive than the provocation techniques in determining airway reactivity but there is no reason to believe that it is not specific. Beta-agonists have been shown to reverse completely the bronchoconstriction induced by provocation tests $s^{15}$ and both methods may test the same phenomenon. The prevalence of airway reactivity in this population $(11.6 \%)$ is similar to that described in other populations including a rural Australian population $(11.4 \%)^{12}$ : it is higher than might have been expected for this group of men who originate from rural areas of southern Africa where the prevalence of asthma is low. ${ }^{16}$

The choice of a more than $10 \%$ increase in FEV after salbutamol is less than that usually used for clinical diagnostic purposes but seems to have been appropriate in this epidemiological study. By making the test more sensitive and thus less specific, there would be a tendency to diminish any differences between those with a positive and those with a negative test result. Thus, if anything, the differences in lung function shown between those with and those without airway reactivity have been understated. Similarly, the failure to identify those with airway reactivity by their symptoms would have been even more striking if a stricter definition of airway reactivity had been used.

This study has been unable to show any relation between the presence of airway reactivity and this occupational exposure. The stable prevalence of airway reactivity across the range of about 10 to 40 years of underground work makes it unlikely that this exposure causes airway reactivity. On the other hand, for any given duration of exposure to dust and controlling for tobacco smoking, lung function is significantly reduced in those with airway reactivity. This finding suggests that men with airway reactivity are more susceptible to the effects of this occupational exposure on the bronchial tree. It has been argued that airway reactivity simply reflects rather than explains reduced airway calibre ${ }^{17}$ but in this working population less than 3\% had a FEV, below 21 and although airway reactivity was more frequent in this small group ( $p<0.05)$, there was no significant influence of airway calibre apparent in the remaining $97 \%$ of the sample.

No relation has been shown between the presence and degree of silicosis and the frequency of airway reactivity.

As has been the case in other studies, ${ }^{12141819}$ the present study has shown that respiratory symptoms, including a history of wheezing, nocturnal cough, nocturnal dyspnoea, and variable dyspnoea, do not adequately predict airway reactivity. In this respect the data from the present study have been similar to those studies in which provocation tests were used to determine airway reactivity.

Smoking has been shown to increase airway reactivity in several studies ${ }^{12172021}$ but in the present study and in that of Dales et al there was no increase in airway reactivity in smokers. ${ }^{18}$ There was a small increase in the frequency of airway reactivity in exsmokers compared with current smokers.

The frequency of airway reactivity has been shown to increase with increasing age in other studies. ${ }^{1921}$ No such relation, however, was shown in the present study which, in that respect, is similar to those of Woolcock et $a l^{12}$ and of Weiss et al. ${ }^{22}$

In conclusion, the findings of this study suggest that gold miners with reactive airways are more susceptible to the adverse effects of the underground environment in which they work. Those with reactive airways have a greater degree of chronic airflow limitation at every level of occupational exposure than do those without evidence of airway reactivity. There is no evidence that airway reactivity is induced by this occupational exposure.

\section{References}

1 Orie NGM, Sluiter HJ, de Vries K, Tammeling GJ, Witkop J. The host factor in bronchitis. In: Bronchitis: an international symposium, 1960, University of Groningen. Assen: Royal van Gorcum, 1961:43-59.

2 Becklake MR. Chronic airflow limitation: its relationship to work in dusty occupations. Chest 1985;88:608-16.

3 Chinn S, Britton JR, Burney PGJ, Tattersfield AE, Papacosta AO. Estimation and repeatability of the response to inhaled histamine in a community survey. Thorax 1987;42:45-52.

4 Occupational diseases in mines and works act, No 78 of 1973. Government Gazette 6 July 1973. (No 3970.)

5 Cowie RL. Silicosis, pulmonary dysfunction and respiratory symptoms in South African gold miners. Cape Town: University of Cape Town, 1988. (MD thesis.)

6 Ferris BG. Epidemiology standardization project. Am Rev Respir Dis 1978;118:55-61.

7 International Labour Office. Guidelines for the use of ILO international classification of radiographs of pneumoconioses. Rev ed. 
Geneva: International Labour Office, 1980.

8 SAS Institute Inc. SAS/STAT guide for personal computers. 6th ed. Cary, NC: SAS Institute Inc, 1985.

9 Crapo DO, Morris AH, Gardner RM. Reference spirometric values using techniques and equipment that meet American Thoracic Society recommendations. Am Rev Respir Dis 1981;123:659-64.

10 Campbell AH, Barter CE, O'Connell JM, Huggins R. Factors affecting the decline of ventilatory function in chronic bronchitis. Thorax 1985;40:741-8.

11 Lorber DB, Kaltenborn W, Burrows B. Responses to isoproterenol in a general population sample. Am Rev Respir Dis 1978;118:855-61.

12 Woolcock AJ, Peat JK, Salome CM, et al. Prevalence of bronchial hyperresponsiveness and asthma in a rural adult population. Thorax 1987;42:361-8.

13 Robbins JJ. Airway reactivity and the need for a simple test. Am Rev Respir Dis 1980;122:659-60.

14 Pratter MR, Hingston DM, Irwin RS. Diagnosis of bronchial asthma by clinical evaluation. Chest 1983;84:42-7.

15 Chatham M, Bleecker ER, Normal P, Smith PL, Mason P. A screening test for airway reactivity. An abbreviated methacholine inhalation challenge. Chest 1982;82:15-8.
16 Weinberg EG, Van Niekerk $\mathrm{CH}$, Shore SC, Heese H de V, Van $\overline{\bar{Z}}$ Schalkwyk DJ. Prevalence of asthma. Lancet 1977;ii:500.

17 Taylor RG, Joyce H, Gross E, Holland F, Pride NB. Bronchial $\vec{\Phi}$ reactivity to inhaled histamine and annual rate of decline in尺 FEV, in male smokers and ex-smokers. Thorax 1985;40:9-16.

18 Dales RE, Ernst P, Hanley JA, Battista RN, Becklake MR. Prediction of airway reactivity from responses to a standardised respiratory symptom questionnaire. Am Rev Respir Dis 1987;135:817-21.

19 Enarson DA, Vedal S, Schulzer M, Dybuncio A, Chan-Yeung M. Asthma, asthma-like symptoms, chronic bronchitis and the degree of bronchial hyperresponsiveness in epidemiologic surveys. Am Rev Respir Dis 1987;136:613-7.

20 Gerrard JW, Cockcroft DW, Mink JT, Cotton DJ, Poonawala R, Dosman JA. Increased non-specific bronchial reactivity in $\vec{\circ}$ cigarette smokers with normal lung function. Am Rev Respir Dis 1980;122:577-81.

21 Burney PGJ, Britton JR, Chinn S, et al. Descriptive epidemiology? of bronchial reactivity in an adult population: results from $\mathrm{a}_{\odot}$ community study. Thorax 1987;42:38-44.

22 Weiss ST, Tager IB, Weiss JW, Munoz A, Speizer FE, Ingram RH. Airway responsiveness in a population sample of adults and children. Am Rev Respir Dis 1984;129:898-902. 